Environmental Education Research

Vol. X, No. X, Month 200X, 000-000

\title{
Unsettling orthodoxies: Education for the environment/ for sustainability
}

\begin{abstract}
In this paper I employ Foucault's notion of governmentality to reflect on a debate that occurred in the pages of this Journal some ten years ago (Jickling and Spork; Fien). I argue that their exchanges indicate ways in which various positions are engaged in a struggle for dominance in this field, and how particular strategies are used to legitimate and maintain these positions. My purpose is not to propose a new orthodoxy - or even to critique those we have - but rather to raise questions about how the unquestioned 'that-which-is' of orthodoxies comes to be, and their effects. I also suggest that as environmental educators and researchers, we need to work harder to unsettle more often the taken-for-granted in environmental education so that we remain alert to our own easy acceptance of orthodoxies. Without this, we risk our exhortations to those we seek to educate - to think critically, to question assumptions, and so forth - becoming empty rhetoric if we are not practising these ourselves - examining our own, as well as others, assumptions and practices.
\end{abstract}

Keywords: Governmentality, Power, Education for the environment, Foucault, Environmental education 


\section{Introduction}

About ten years ago, in the pages of Environmental Education Research, Bob Jickling and Helen Spork (1998) argued that 'education for the environment' had become nothing more than a slogan, past its use-by date, and in need of retirement. John Fien (2000), long an advocate of 'education for the environment', responded to these charges by arguing that Jickling and Spork had provided only a partial interpretation of this approach, attributing this to their lack of reflexivity over their own ideological stance, and failure to see that the “liberal” position (which he argued they subscribed to) dominates environmental education.

In this paper, I seek to re-examine this debate, to understand how this is indicative of what I see as the development of 'education for the environment' as orthodoxy within the field of environmental education, in the realm of theory if not practice. While some may see this as a return to an old debate, I think it timely to revisit it now, for two reasons. First, it is quite difficult to see the various positions that govern our thinking as they occur and while they still appear as possible solutions to our problems. It is, however, somewhat easier to identify and examine these 'historically'. Second, we are halfway through the United Nations Decade of Education for Sustainable Development (UN DESD). While some may question whether 'education for the environment' is (or, for that matter, has been or ever was) an orthodoxy for the field, the grounds for investigating such a claim are readily illustrated in recent shifts in the terminology employed within the field. For example, the naming of the UN Decade as 'education for sustainable development', and its focus on an education through which individuals and societies can "learn the values, behaviour and lifestyles required for a sustainable future and for positive societal transformation” (UNESCO 2007: 2) is a strong indicator of the orthodoxy of the notion that environmental education should be 'for' something - namely, preparing individuals to be socially critical in order that they are willing and able to bring about “societal transformation” (ibid.). Readers may also question an apparent conflating of 'education for the environment' with 'education for sustainable development' or 'education for sustainability'. However, I argue that while many have shifted their focus from environmental education to education for sustainability, this shift seems to have occurred despite the concerns raised by some environmental education scholars (see, for example, Stevenson 2006, Jickling \& Wals 2008, Nomura \& 
Abe 2009). ${ }^{\mathrm{i}}$ Thus, I point to some of the immediate similarities between 'education for sustainable development' and 'education for the environment', such as their shared goal of a society transformed into a sustainable society, and their shared belief that the goal of education is to enhance the capacities of individuals so that they can bring about personal and social change - be this 'for sustainable development' or 'for sustainable lifestyles', as the ultimate goal of each is respectively articulated (see, for example, Jickling \& Wals 2008).

I also think it is timely to reflect on why the debate between Jickling, Spork and Fien bubbled to the surface and then disappeared without a trace, and how this may be an indication of the ways in which discourses compete with one another for positions of dominance within knowledge domains such as environmental education. The purpose here is not to comment on the veracity or otherwise of the authors' respective claims, nor to critique or valorize either a 'socially critical' or a 'liberal' approach to environmental education. I do not wish to contribute to the debate by providing evidence to either support or refute the 'truth' of either position or the claims they make. Neither do I offer a reading of the 'what' or even the 'why' of these positions.

Instead I take a more novel approach of examining the 'how' of these positions: how do positions compete for dominance in a field and, most importantly, how do these positions have effects that govern what it is possible to think and what it is possible to do in environmental education. Such a reading is important because, as Nikolas Rose (1999: 9) reminds us, “concepts are more important for what they do than for what they mean” and we seem to most often discuss what concepts contain, signify and mean (for those who develop them and those who interpret and/or critique them) rather than what they do, that is, the effects they have. Thus I offer this reading not as a critique of either position but in the spirit of "generous scholarship”, of which Russell (2006) speaks, in and for the field.

I begin by further outlining the similarities I see between 'education for the environment' and 'education for sustainability', before turning to some of the indications that 'education for the environment' can be seen (theoretically at least) as an orthodoxy for the field. 


\section{'Education for the Environment'}

There are a range of defining characteristics underpinning 'education for the environment' that its proponents argue will lead to the empowerment of individuals and the transformation of social structures. According to Fien, these are:

- the development of a critical environmental consciousness,

- the use of critical thinking and problem solving skills,

- the development of an environmental ethic,

- the development of political literacy, and

- "critical praxis", that is, teaching strategies that are consistent with the goals of 'education for the environment' (1993: 12, 50-75).

These characteristics display a commitment to identifying and recognising underlying ideological stances and to adopting a new ideology. According to Tilbury (1995), one of the leading advocates of 'education for sustainability' (who has also been a strong advocate of 'education for the environment' in the past), 'education for sustainability' also focuses on empowering individuals and transforming social structures, through an education that:

- is relevant in that it deals with contemporary issues of concern to the learner,

- is holistic in addressing environmental issues and in teaching and learning,

- not only teaches about values but also teaches values, in this case 'an environmental ethic which has sustainable living at its core' (1995: 201),

- is issues-based, to allow for an 'exploration of moral, social and political values required for the development of an environmental ethic' (1995: 202),

- has an action-orientation, both in encouraging learners to take actions to bring about change in their own lives and in their communities, and in promoting the use of active teaching and learning strategies, and

- involves critical education, that is, an education that develops socially critically and political literacy skills, essential, she argues, to ‘achieving “sustainability”' (1995: 204).

At face value, these are remarkably similar in their intent and focus to the characteristics outlined by Fien, and to those later outlined in the UNESCO Johannesburg definition of 
'Education for Sustainable Development' as “a concept that encompasses a new vision of education that seeks to empower people of all ages to assume responsibility for creating a sustainable future” (UNESCO 2002: 5). Each description articulates a shared belief that education should enable (either through "empowering” or "enhancing capacity”) the sort of social change that will bring into being a sustainable society and/or future.

Governments have also - perhaps surprisingly - taken up the social change orientation of 'education for the environment'. For example, the Australian Government argues that “[e]nvironmental education for sustainability involves" the rather lofty and paradoxical ${ }^{\text {ii }}$ goal of "developing the kinds of civic values and skills that empower all citizens to be leaders in the transition to a sustainable future” (Australian Government and Curriculum Corporation 2005: 8) and more recently: “Through information and awareness, but more importantly by building people's capacity to innovate and implement solutions, education for sustainability is essential to re-orienting the way we live and work and to Australia becoming a sustainable society (Australian Government 2009: 3). Such a desire on the part of a government indicates that the discourse of 'education for the environment', with its vision of empowering individuals to transform themselves and their worlds now so that they can have sustainable societies in the future, has become the unquestioned 'that-which-is' the orthodoxy - in environmental education in Australia, so much so that it is even a goal that the Government aspires to. Is this an indication that the view that environmental education should empower individuals to bring about social change is now orthodox in our field? Indeed, could it even be suggested that the way in which the word for is no longer italicised in the terms 'education for sustainable development' or 'education for sustainability' provides another indication that the notion of 'education for' is now orthodox?

\section{Towards an analytics of government perspective}

How we come to such a remarkable situation - where a position of critique of the norm becomes the norm - is intriguing, especially for a position so focused on social transformation as 'education for the environment' is. Is it really the case that even 
governments, traditionally seen as the opponents of social change and against the empowerment of the people, are supporting and indeed promoting such a position?

To explore these matters further, in this paper I draw on ideas encapsulated in Michel Foucault's (1991) notion of governmentality. Three key concepts underpin the notion of governmentality: power, knowledge and the self. These concepts, as framed by Foucault, present an understanding of power not as repressive but as consisting of productive power relations, as dispersed outside of the State, and as productive of new truths and capacities. They offer an understanding of what Foucault refers to as 'power/knowledge', where knowledge is both essential to the exercise of power and a product of power. They also offer an historical and cultural understanding of the self that allows the ways in which power, knowledge and the self are intimately and distinctively interconnected within societies with liberal modes of rule to be understood. As I aim to show, these ideas provide a way for us to grapple with understanding how a position of critique is able to become that of orthodoxy.

Foucault challenges traditional conceptions of power by claiming that power is not held only by those who are in power but is rather dispersed and operates through relations of power. For Foucault, power cannot be reduced to "an institution, a structure or a certain force with which people are endowed; [but is rather] the name given to a complex strategic relation in any given society” (in Gordon 1980: 236). Power here is "quite different from and more complicated, dense and pervasive than a set of laws or a State apparatus” (Foucault 1980a: 158). Power relations are not simply uni-directional and linear, in the way that power exercised by "the State" over "the people", or the potential power of "civil society" over "the State", are often conceived. Nor does power originate from a single source: it is not "built up out of "wills" (individual or collective), nor is it derivable from interests" (Foucault 1980b: 188). Neither is it unified in intents or in its effects. Rather, Foucault argues that "power in its exercise goes much further, passes through much finer channels, and is much more ambiguous” (1980c: 72) than those accounts which claim that power originates from a single source would have. Such relations of power exist inside, outside and alongside the State. 
Foucault's investigations of the history of our present ways of knowing and doing in a range of institutions and situations demonstrates how relations of power and their concomitant mechanisms are dispersed through a range of governmental systems and agencies, as well as through organizations, bodies of knowledge and individuals thought to be outside the realm of the state. Power here then does not refer only to the exercise of political power. What Foucault's studies offer to environmental education is a way to understand how power operates both inside and outside the realms of the state or other political structures within modern liberal modes of governance. Grasping this, however, entails letting go of an understanding of power as the exclusive domain of the few - the powerful - and of the exercise of power as repressive and linear.

The key contribution Foucault's studies offer in this regard, I would suggest, is that the relationship between power (as productive not as repressive and as dispersed outside of "the State"); knowledge (where knowledge is the product of power as well as essential to the exercise of power); and the self (as both an object of power/knowledge and a subject of power/knowledge) is made evident. The notion of "governmentality" (Foucault 1991) - our "mentalities" or thoughts about how we govern ourselves and how we govern others - acts as a shorthand for these key propositions and understandings.

In undertaking the analysis in this paper, I use a quasi-methodological approach referred to as 'an analytics of government'. Foucault himself only ever spoke retrospectively of methodological issues and did not articulate a single or clear methodology or set of methods for his work. As O’Farrell (2005: 50) notes, “Foucault continually changed and refined his concepts, not only on a major scale, but in very minute and subtle ways, something which makes his work extremely difficult to systematise for the purposes of a methodical and wholesale application”. Foucault's initial ideas about how to undertake studies of our 'govern-mentalities' have underpinned efforts by Foucault scholars - in particular the Anglo-Foucauldians (see, for example, Dean 1994, 1999, 2007; Kendall \& Wickham 1999; Miller \& Rose 2008; Rose 1999) - to develop a methodological framework for examining governmentality 'in action', referred to now as an analytics of government. An analytics of government is thus a means for investigating practices that direct conduct, and for 
investigating the forms of thought or mentalities that guide such practices (Dean 1999: 3640).

It is important to note that an analytics of government does not search for ultimate goals or transcendent principles that should or should not direct the ways in which we govern and are governed. It does not propose new, utopian solutions. Instead, such an approach is concerned with gaining purchase on governmental regimes by clarifying their forms of thought - their mentalities - and by examining the effects of these at their point of application. Thus an analytics of government does not seek to understand discourses linguistically or to undertake micro-level critical analyses using linguistic methodologies. Rather, it is a form of philosophical enquiry interested in understanding the formation of discourses, how they become legitimate, how they are distributed, how they maintain their legitimacy, and what effects they have on how we think about and seek to govern our own conduct and the conduct of others. In short, such an analysis does not provide glossy or easy answers to problems but instead provides new, often troubling, insights that challenge us to think differently about problems.

Such an analytics of government perspective then, offers a means for exploring how environmental education as a discipline is engaged in exercises of power through the generation of a range of positions that come to be, through a process of internal struggle within the field, seen as truths or orthodoxies. As truths or orthodoxies they are often unquestioned as their truth seems self-evident, or is so embedded as 'that-which-is' that we seldom question them. These orthodoxies are important to examine not to prove them 'wrong' or 'untrue' but in order to understand how they work as rationalities of rule that govern how things can be thought, understood and done in environmental education. Positions, once they have gained the status of truth or orthodoxy, are thus not only exercises of power that seek to challenge and critique, but also exercises of power that work to govern thought and practice within a field. This is because such orthodoxies carry with them a range of semi-normative prescriptions that work to include, exclude and govern what it is acceptable (possible) to think, and what it is acceptable (possible) to do, in environmental education. 
There are many ways in which orthodoxies come to be established, legitimated, maintained, and distributed in a field. In this paper, I examine only one instance that I read as the legitimation and maintenance of 'education for the environment' as orthodoxy in and for the field of environmental education ${ }^{\text {iii }}$. Such an examination is important as it helps us to “interrogate the "rationality” of the present” (Gordon 1980: 242), that is, to illuminate how certain points of view have become 'normal', 'everyday' and 'obvious' in our thinking and practices. In this way we might better understand, for example, how we have come to, in many settings, see 'education for the environment' - that is, education that seeks social transformation through individual empowerment - as the most, perhaps only, legitimate approach to environmental education.

\section{Discourse struggles}

One of the methodological techniques through which to make visible the establishment of a position as orthodoxy is an examination of the power relations evident in 'discourse struggles' within a field of endeavor. In illustrating my argument that 'education for the environment' has come to be accepted as orthodoxy in our thinking - or mentality - about how best to 'do' environmental education, this paper describes one instance of a struggle that has taken place in environmental education over whether environmental education should be 'for the environment', that is, a way to empower individuals to transform their society into a sustainable one. This debate has occurred largely between those who are deemed - by each other and by themselves - to hold 'critical' and 'liberal' philosophical positions on education. A case in point of this debate can be found in the Jickling and Spork (1998) and Fien (2000) papers.

The Canadian scholar, Bob Jickling, has been vocal in challenging the notion that education more generally, and environmental education in particular, should be 'for' empowering individuals to transform social structures. Jickling's argument is that 'education for the environment' is more activism than education, with its focus on educating towards a particular mindset and set of values (see, for example, Jickling 1991, 1992, 2005). Jickling’s 
position is that we should not "apply the term education to the achievement of some particular end" and that education "transcends immediate instrumental values such as the advocacy of a particular sort of behaviour” (Jickling 1991: 172). Therefore, he argues, "while it may be important for citizens to promote changes in attitudes and behaviours, this must not be confused with our work as educators” (Jickling 1991: 171). For Jickling, education is something other than - and more than - simply training people to take on a particular point of view or particular sets of practices. His critique then, is with what he sees as the 'deterministic' nature of 'education for the environment'.

In contrast, Fien (see, for example, Fien 1993, 1997, 1999/2000, 2000, 2002) and others (see for example, Palmer 1998, Tilbury 2004, van Rossen 1995) have argued that the goal of environmental education should be to empower individuals to transform society. Such sociocritical environmental educators argue that this is not to be achieved through training people to take on a particular point of view, as Jickling claims, but through an education that seeks to develop a critical consciousness, political literacy and an environmental ethic, through the use and development of critical thinking and socially critically teaching and learning strategies (Fien 1993: 12, 50-75).

These two positions have engaged directly with one another in the Jickling and Spork (1998) and Fien (2000) papers. In 1996, Jickling and Spork presented a paper at the American Educational Research Association (AERA) conference in New York titled 'Environmental education for the environment: Retained or retired?' (Jickling \& Spork 1996). In a revised version of this paper, published in 1998, they argue that the term 'education for the environment' needs to be retired as it has become a slogan (Jickling \& Spork 1998). They also claim that there has been very little critique in environmental education of Arthur Lucas' (1979) categorisation of environmental education as education 'about, in or for' the environment, to the point that each of the prepositional forms have become mere slogans. In particular, they argue that the term 'education for the environment' is used uncritically, that is, 'interpreted literally’ (Jickling \& Spork 1998: 311). Their problem with this is that terms can 'acquire different meanings and serve new purposes' (Jickling \& Spork 1998: 311). In supporting this claim, they use as an example the shift that has occurred since the initial use 
of the term by Lucas - as a 'descriptive' protocol to distinguish it from education about and in the environment - to its later use by its advocates as an 'analytical standard' or evaluative protocol (Jickling \& Spork 1998: 312), as Fien does, for example, in arguing that identifying underlying ideologies helps to provide a means for developing a framework to elaborate “characteristics by which environmental education programmes can be scrutinised for their counter-hegemonic potential” (Fien 1993: 11).

The effect of the term being used as an analytical standard troubles Jickling and Spork. They argue that "[c]ontinued analytical use (see for example Fien, 1993a) can lead to exclusiveness and serve to entrench [the] perception" that only "education for the environment' is “correct” environmental education (Jickling \& Spork 1998: 312). In addition, they argue that what they see as the sloganistic use of 'education for the environment' lacks clarity, imposes a particular moral viewpoint, and discourages and confines discussion within the field. They argue that the term thus needs to be retired not only because it has become a slogan but also because its language reflects the values and predilections of activists, not educators. For them, “continued popular use of the term runs the risk of encouraging non-educative activities” (Jickling \& Spork 1998: 323).

For Jickling and Spork, any approach to education that claims to be critical and encourage critical thinking but that has a pre-determined outcome is problematic:

The crux of the problem is, however, structural. When we talk about "education for the environment" we imply that education must strive to be "for" something external to education itself. Unfortunately, there is an oxymoronic quality embedded in this construction. If we want students to examine ideologies, criticise conventional wisdom and participate in cultural criticism and reconstruction, then we must accept that they may well reject the externally imposed aim that has been pre-selected for them. If we are serious about education, we should, in the first place, put aside our most promising visions for the future. Moreover, if we really want to open students' minds to alternative world views, it makes little sense to steer them, however gently, towards a particular vision. The prepositional use of "for" ultimately leads, therefore, to either a literal or programmatic interpretation which is, in our view, deterministic. (1998: 323-4) (Authors’ emphasis)

The issue not addressed by Jickling and Spork, however, is how and in what ways education can be anything other than the achievement of some particular end, even if this is as 
nebulous as a 'well-rounded' or 'educated' person, or the development of citizens or critical thinkers.

Despite their criticisms of 'education for the environment', Jickling and Spork do acknowledge that it has been useful in drawing attention to the social and political aspects of environmental problems, and as a practical framework for those seeking to empower themselves and/or their students to act for the environment:

On the positive side, it is important to recognise that activities labelled "education for the environment" have helped to place, and keep, the political dimension of issues on the environmental education agenda. As thinking about the term has developed, the socially critical dimension of environmental education has been illuminated and has thus helped to give life to this field in the face of conservative influences. The term and its various stipulations has also been a useful tool for teachers and other practitioners for discovering overlooked dimensions of their work. A critique such as ours must acknowledge and value these contributions. (1998: 323)

It is finally their contention, though, that these positive features are outweighed by the negative impacts of the sloganistic and analytical use of the term. To provide a sound educational experience, Jickling and Spork maintain, environmental educators need to:

acknowledge that shaping the future does not consist of being led to adopt some alternative vision. Rather, it involves the more indeterminate process of examining and re-casting society. If we acknowledge that education should be free of specified ends, then we are ultimately led to challenge the way in which "education for the environment” operates to predetermine educational aims. (1998: 325)

As noted previously, what Jickling and Spork fail to address is that education - be it that provided by State, church or independent schools - is purposive: to form and shape particular types of persons, for example, 'critical thinkers'. As Hunter (1994) noted in his history of education in Western liberal societies, all education seeks to govern our conduct by teaching us how to self-govern our conduct. For the purposes of the argument I am posing here, however, the claimed 'truth' of either of these positions of principle is of less interest to my argument than their effects.

\section{What happened next?}


When the Jickling and Spork paper first appeared as a conference presentation at AERA in 1996, there was great interest in the issues raised, with for example, discussion groups held in the United Kingdom following the AERA conference that included discussion of the paper. Unsurprisingly, advocates of the 'education for the environment' approach were quick to respond. For example, Joy Palmer, who at the time was a leading researcher in the field and author of key environmental education texts, argued thus:

[S]urely it is important to retain goals and terms that have actually served and continue to serve the critical function of assisting teachers and other practitioners to discover overlooked and important dimensions of environmentalism. I would actually go further than this, and say that an understanding of the phrase "education for the environment" ... has been the bedrock stimulus for the practical development of environmental education programmes in classrooms around the world. ... Countless students and teachers have found the use of the word "for" in relation to the environment most helpful when coming to grips with criticism of conventional wisdom, consideration of alternative worldviews and formulation of attitudes and values that will enable us to recast society for the better. ... To lose sight at this stage of the accepted terminology is to lose sight of important research findings that reveal the critical role of "in the environment" and "about the environment" experiences in terms of illuminating an understanding of actions "for the environment". ... Surely the ... language of the field of environmental education similarly awaits the appropriate time for reformulation.' (Palmer 1998: 238-9)

From an analytics of government perspective, Palmer's argument illustrates two interesting issues: how proponents of particular positions - despite the status or standing of the position within a field - retain a capacity to see their position as the position of challenge and oppositional criticism, not as the orthodoxy; and how such proponents seek, through their responses, to maintain their position of dominance by simply declaring, for example, 'now is not the appropriate time'.

In Fien’s (2000) response he argued that Jickling and Spork had presented only a partial interpretation of 'education for the environment', one driven by their own beliefs:

Thus, [Fien's] article addresses Jickling and Spork's concern that education for the environment is a universalising discourse that seeks to marginalise other approaches. It does this by showing how it may be Jickling and Spork's lack of reflexivity over their own ideology of education which leads them to construct such a partial interpretation of education for the environment. (Fien 2000: 179) 
For Fien, Jickling and Spork's argument "is not of education for the environment as it has been developed in the literature but of a partial reading that has been constructed through an unacknowledged but, nevertheless, ideologically motivated and literal textual reading” (Fien 2000: 186). Fien contrasts what he sees as a failure on the part of Jickling and Spork to reflect on their own beliefs and ideology with "the way many practitioners of a critical education for the environment have been open in describing the approach as an integration of "red-green" environmentalism and socially-critically approaches to education" (2000: 181). The effect of such a claim is that it provides Fien with a more principled position than Jickling and Spork's.

In understanding the range of mechanisms of power that operate to legitimise and maintain orthodoxies, it is significant to note here that Fien's response takes the form of a moral critique. For Fien, it is Jickling and Spork's "lack of reflexivity", their "lack of openness about their own ideological dispositions”, that is the problem (Fien 2000: 181). Moreover, two of the hallmarks of the socio-critical stance underpinning 'education for the environment' are "reflexivity and self-critique” (Fien 2000: 184), thus making it impossible, from this perspective, that 'education for the environment' could be constraining debate in environmental education. Indeed, Fien argues that "education for the environment is based upon and embodies education in and about the environment” (Fien 2000: 183), and as such, is not deterministic or purposive but rather inclusive of all environmental education approaches. In support of his argument, he cites a passage from his 1993 text, Education for the Environment: Critical curriculum theorising and environmental education, which talks about the type of reflective and self-critical work one needs to undertake as a "transformative intellectual”, work such as:

actively theorizing upon one's own environmental and educational ideologies, ... This is one of the secrets of success in being a transformative intellectual. There are others of course, including perseverance and hard work, constantly being open to ideas and constructive critique, political literacy and a keen eye for strategic opportunities, and courage, skill and patience in dealing with the arguments and possible complaints of those whose teaching serves the interests of the Dominant Social Paradigm. However, the hallmark of a transformative intellectual is her and his "inner life", that commitment to ecological and social justice and transformation, which is sustained not only by moral outrage (and we do need our share of that) but 
also by the habit of critical reflection upon one's views and work (Fien 1993: 98 in Fien 2000: 185).

What is clear here - when we look at it through a governmentality lens - is the rationality of rule evident in this quote: to be a critical environmental educator who is also a transformative intellectual - and thus not one who "serves the interests of the Dominant Social Paradigm” (ibid.) - one must ensure that one is capable of, and practices to the point of forming a habit, reflexivity and self-critique. Put simply, this statement illustrates a 'govern-mentality': it indicates that one should be a transformative intellectual (the self as object), and the practices to follow to be a transformative intellectual (the self as subject). When we have the 'mentality' that it is necessary to be critically reflexive, this has an effect on what we do as environmental educators, to ourselves and to others such as our students. In undertaking and encouraging such practices, we work to govern our own and others conduct. Thus it is an example of a mentality that governs how we think and how we act in environmental education.

It is perhaps worth noting here that the practices of reflexivity and self-critique have a religious history, arguably one that has been more connected to governing and reforming conduct than it has been to fostering emancipation and liberation. Indeed, Fien is correct in referring to this type of work as habit-forming as it is work that fashions a new type of persona: the self-governing, and self-regulating, transformative intellectual. However, what he misses is that this work occurs within the limits of the normative prescriptions imposed by socio-critical theory ${ }^{\text {iv }}$. It is such normative prescriptions that work to govern how we think and how we act in environmental education.

Moreover, not only are such prescriptions normative, but successfully so in environmental education: there is little critique of an environmental education that seeks to empower individuals to transform society, and even less critique of the concepts of reflexivity, democracy, social justice, empowerment or transformation. Foucault's studies make clear the ways in which the setting in which an orthodoxy is located helps to legitimise and maintain it. We now live in a time, for example, when it is politically incorrect - almost impossible - to critique concepts such as democracy, empowerment and citizenship without 
being accused of 'walking with the devil on the dark side'. This setting - and its attendant normativities - allows Fien to accuse his detractors of failing to be reflexive, while at the same time failing to acknowledge the normativity of his own position. Fien is partly able to make such a charge because it is unlikely that - at this moment in our history - many will speak out against the desirability of these things. To re-iterate, this is not to imply that such practices are 'bad' or should not be used in environmental education but rather to suggest that such practices - when linked to positions of principle - work to govern and shape our conduct - and it is because of this 'power' that we need to be alert to the effects of our govern-mentalities.

Fien concludes his paper with the suggestion that we need to better understand why scholarly disputes are a part of academic culture. He argues that he is "increasingly coming to see Foucault's notion of discourse as power/knowledge as an important way of explaining this” (Fien 2000: 188). His understanding of Foucault's concept of power/knowledge leads him to argue that:

it could be that the critique presented by Jickling and Spork (1998) represents not a critique of education for the environment, per se, but an attempt to control the influence of critical environmental education through the power/knowledge of liberal educational and environmental discourses. ... Their desire to control discourse in environmental education is also revealed by their attempts at limiting who is entitled to speak about the field. Numerous examples of this are found in the paper. For example, Jickling and Spork allege that several Canadian educators are "refusing to engage in serious discussion" as they "champion the conversion of environmental education into 'education for sustainable development'”. Two techniques for controlling discourse are evident in this brief passage. One is Jickling and Spork's failure to declare their own positions within environmental education debates and, thereby, attempt to construct themselves as disinterested commentators ... The second technique of control evident in this passage is the attempt to marginalise the voices of other researchers through the use of loaded terminology, in this case, through the use of terms such as "serious discussion", "champion" and "conversion". The use of such vocabulary may be interpreted as an attempt to construct others as unworthy commentators who "champion" ideas, rather than "argue" for them, who want to "convert" environmental education rather than "reorient" it towards sustainability, and whose work cannot be described as a "serious discussion". (Fien 2000: 188)

From a governmentality perspective, Fien has correctly read the situation. However, he fails to signal that he himself is a part of this power relation (as am I in writing this paper and 
engaging with this debate). Rather, Fien seems to situate 'education for the environment' as somehow standing outside of this power relation, as the voice oppressed by the dominance of liberal educational and environmental discourses. He may well be correct about which position dominates thinking in the field, although I have put a contrary position here. However, as I noted at the beginning of this paper, my interest is not in seeking to claim one or other position of principle as 'true'. Rather, my aim in writing this paper is to illustrate that it is difficult for us to understand the effects of positions of principle when they become orthodox - 'that-which-is' - as their ‘obviousness' makes it difficult for us to question them.

Thus Jickling, Spork and Fien, in engaging in this debate, are all working to "control discourse in environmental education” (Fien 2000: 188), as am I, to some extent, in writing this paper. The great insight that Foucault offers is that we are all constantly engaged in these power relations and that none of us sit outside them. What is interesting to me, in seeking to understand the effects that various positions have on governing thinking and practice within a field, is why Jickling and Spork chose not to respond to the Fien paper, despite claiming in their 1998 paper that they wanted to encourage debate in the field about this issue. In seeking to understand why Jickling and Spork did not respond, I asked them. According to Spork (pers. comm., 2008) it was not because she felt proven wrong by Fien’s arguments in his 2000 paper, but because she thought the discussion would quickly degenerate if they responded and that she preferred to leave it open for others in the field to respond. None did in this or other journals. According to Jickling (pers. comm., 2007) he was actively discouraged from responding to Fien's paper in Environmental Education Research by a then member of this Journal's editorial team. Despite their different explanations, the interesting issue given the burden of this paper in trying to understand relations of power is why only Palmer (1999) and Fien (2000) responded to the Jickling and Spork call for the field to debate the issue. Did everyone agree with Palmer and Fien's response and feel there was nothing more to say? Were people afraid of possible repercussions from being seen to be speaking out for one or the other side of the debate? Or could it be that this is another remarkable feature of such discourse struggles, that when a position is orthodox, alternative positions struggle to find additional supporters, or at least supporters who will 'speak publicly' (see also Russell, 2006). Could it be that through such 
strategies orthodoxies come to be maintained and so to govern what can be thought - and what can be said - within a field?

\section{Conclusion}

In conclusion, the reading I have undertaken in this paper offers one way for us to think about orthodoxies and their alternatives in our field. I am not arguing for one or another orthodoxy - indeed whichever position manages to become dominant will become orthodox and remain so until there is enough critique of it for its position of dominance to be challenged. What an analytics of government reading of this debate helps to illustrate, however, is not that one discourse has become orthodox as an inevitable result of the 'correctness' or 'truth' of its principles but rather that it has, for a moment, won a battle between competing discourses. Indeed, in unsettling 'that-which-is', I hope I have demonstrated that 'education for the environment' may not be 'the truth' but simply a rationality or mentality that currently rules or governs contemporary environmental education thought and practice.

Proponents of an orthodoxy will no doubt not see or understand their position in such governmental terms. However, when governmental terms - such as understanding orthodox approaches to environmental education as rationalities of rule - are adopted, certain new emphases emerge that allow us to jettison an orthodoxy's self-understanding in favour of a different - perhaps more precise and accurate - understanding of how we as environmental educators govern our own - and govern others - thought and practice. The point of such an unsettling of 'that-which-is' is that it offers a reminder that we need to remain vigilant in environmental education to our own rhetoric - and vigilant of the ways in which such rhetoric is indicative of rationalities of rule through which we are governed and through which we seek to govern others, that is, of our own 'govern-mentalities'. It is only through making these visible that we are able to reflect on their effects on our thoughts and practices, and to consider whether to keep using them or seek to change them.

\section{Acknowledgements}


I wish to thank the reviewers of this paper for their very thoughtful and detailed suggestions as well as Professors David Saunders and John Fien for discussing this paper with me.

\section{References}

Australian Government and Curriculum Corporation. 2005. Educating for a sustainable future: A national environmental education statement for Australian schools. Canberra: Australian Government Department of the Environment and Heritage.

Australian Government. 2009. Living Sustainably: The Australian government's national action plan for education for sustainability. Canberra: Department of Environment, Water, Heritage and the Arts.

Dean, M. 1994. Critical and Effective Histories: Foucault's methods and historical sociology. London: Routledge.

Dean, M. 1999. Governmentality: Power and rule in modern society. London: Sage Publications.

Dean, M. 2007. Governing Societies: Political perspectives on domestic and international rule. Maidenhead: Open University Press and McGraw-Hill Education.

Fien, J. 1993. Education for the environment: Critical curriculum theorising and environmental education. Geelong, Vic.: Deakin University.

Fien, J. 1997. Stand Up, Stand Up and Be Counted: Undermining Myths of Environmental Education. Australian Journal of Environmental Education 13: 21-26.

Fien, J. 1999/2000 Education, Sustainability and Civil Society. Australian Journal of Environmental Education 15/16: 129-131.

Fien, J. 2000. 'Education for the environment: A critique': An analysis. Environmental Education Research 6, no. 2: 179-192.

Fien, J. 2002 Education and Sustainability: Reorienting Australian Schools for a Sustainable Future, Tela Papers, No. 8. Melbourne: Australian Conservation Foundation.

Foucault, M. 1980a. The eye of power. In Power/knowledge, selected interviews and other writings 1972-1977, by Michel Foucault. ed. C. Gordon, 146-165. Hertfordshire: Harvester Wheatsheaf.

Foucault, M. 1980b. The history of sexuality. In Power/knowledge, selected interviews and other writings 1972-1977, by Michel Foucault. ed. C. Gordon. 183-193. Hertfordshire: Harvester Wheatsheaf.

Foucault, M. 1980c. Questions on Geography. In Power/knowledge, selected interviews and other writings 1972-1977, by Michel Foucault. ed. C. Gordon. 63-77. Hertfordshire: Harvester Wheatsheaf.

Foucault, M. 1991. Governmentality. In The Foucault effect: Studies in governmentality with two lectures by and an interview with Michel Foucault. eds. G. Burchill, C. Gordon and P. Miller. 87-104. Chicago: The University of Chicago Press.

Gordon, C. 1980. Preface and afterword. In Power/knowledge, selected interviews and other writings 1972-1977, by Michel Foucault. vii-x; 229-260. Hertfordshire: Harvester Wheatsheaf.

Hunter, I. (1994) Rethinking the school: Subjectivity, bureaucracy, criticism. St. Leonards, NSW: Allen \& Unwin. 
Jickling, B. 1991. Environmental education and environmental advocacy: The need for a proper distinction. Canadian Issues 13: 169-175.

Jickling, B. 1992. Why I don't want my children to be educated for sustainable development. Journal of Environmental Education 23, no. 4: 5-8.

Jickling, B. 2005. Education and Advocacy: A troubling relationship. In Environmental Education and Advocacy: Changing Perspectives of Ecology and Education. eds. E.A. Johnson, and M. Mappin. 91-113. Cambridge University Press, Cambridge, UK.

Jickling, B. and Spork, H. 1996. Environmental education for the environment: Retained or retired? American Educational Research Association conference. New York: American Educational Research Association.

Jickling, B. and Spork, H. 1998. Education for the environment: A critique. Environmental Education Research 4, no. 3: 309-327.

Jickling, B. and Wals, A. 2008. Globalization and environmental education: looking beyond sustainable development. Journal of Curriculum Studies 40, no.1: 1-21.

Kendall, G. and Wickham, G. 1999. Using Foucault's Methods. London: SAGE Publications.

Lucas, A. 1979. Interpretations of 'environmental education'. In Environment and environmental education: Conceptual issues and curriculum implications. 50-65. Melbourne: Australian International Press and Publications.

Miller, P. and Rose, N. 2008. Governing the Present: Administering economic, social and personal life. Cambridge: Polity Press.

Nomura, K. and Abe, O. 2009. The education for sustainable development movement in Japan: a political perspective. Environmental Education Research 15, no. 4: 483-496.

O'Farrell, C. 2005. Michel Foucault. London: SAGE Publications.

Palmer, J. 1998. Environmental education in the 21st century: Theory, practice, progress and promise. London: Routledge.

Robottom, I. and Hart, P. 1993. Research in environmental education: Engaging the debate. Geelong, Vic.: Deakin University.

Rose, N. 1999. Powers of freedom: Reframing political thought. Cambridge: Cambridge University Press.

Russell, C. 2006. Working across and with methodological difference in environmental education research. Environmental Education Research 12, nos. 3-4: 403-412.

Stevenson, R. 2006. Tensions and transitions in policy discourse:recontextualizing a decontextualised EE/ESD debate. Environmental Education Research 12, nos. 3-4: 277-290.

Tilbury, D. 1995. Environmental education for sustainability: Defining the new focus of environmental education in the 1990s. Environmental Education Research 1, no. 2: 195-212.

Tilbury, D. 2004. Environmental education for sustainability: A force for change in higher education. In Higher Education and the Challenge of Sustainability: Problematics, promise and practice. eds. P. Corcoran and A.E.J. Wals. 97-112. Kluwer Academic Press, Dordrecht.

UNESCO. 2002. Education for Sustainability: From Rio to Johannesburg: Lessons learned from a decade of commitment. Paris: UNESCO.

UNESCO. 2007. Highlights on DESD progress to date, January 2007. Paris: UNESCO. 
van Rossen, J. 1995. Conceptual analysis in environmental education: Why I want my children to be educated for sustainable development. Australian Journal of Environmental Education 11: 73-81.

Walker, K. 1997. Challenging Critical Theory in Environmental Education. Environmental Education Research 3, no. 2: 155-162.

\footnotetext{
${ }^{i}$ These concerns relate to the various conceptualizations of sustainable development and sustainability (in particular the primacy of the economy and economic development) and the philosophies and ideologies underpinning them, as well as the effects of these on the development of uncontextualised education for sustainability/sustainable development policies and practices.

${ }^{\text {ii }}$ Can all be leaders in the transition to a sustainable future?

iii cf. Nomura \& Abe 2009 on the development of the UN DESD from a political opportunities perspective.

${ }^{\text {iv }}$ For an earlier account, also in Environmental Education Research, see Walker (1997).
} 